\title{
DISCUSSION
}

\section{Some measurements of the permeability of kaolin}

\author{
A. AL-TABBAA and D. M. WOOD (1987). Géotechnique 37, No. 4, 499-503
}

\section{Assistant Professor D. Znidarčić and Saad Ali Aiban, University of Colorado}

The Writers wish to present some additional data obtained independently and with different techniques that confirm the results published in the Paper. For these tests, the speswhite kaolin clay was prepared as a slurry with a water content of $133 \%$ and was then consolidated onedimensionally under an axial stress of $100 \mathrm{kPa}$ in a $203 \mathrm{~mm}$ dia. tube. A stress of $100 \mathrm{kPa}$ was selected as the consolidation pressure, resulting in a sample with relatively high void ratio, yet stiff enough to be trimmed without much sample disturbance. Four cylindrical samples of $71 \mathrm{~mm}$ dia. were obtained from the compressed material. Two of the samples had axes in the vertical direction and two in the horizontal direction. The samples were tested in a flexible wall permeameter using the flow pump technique (Pane, Croce, Znidarčić, Ko, Olsen \& Schiffman, 1983; Olsen, Nichols \& Rice, 1985) to measure permeability.

Cylindrical specimens were placed in the triaxial cell with the porous stones at the top and the bottom and a flexible latex membrane around them. The flow was always in the axial direction, but as different samples were trimmed with their axis in the consolidation direction (or perpendicular to this direction) both vertical and horizontal permeabilities for the material were obtained. Once the specimens were placed in the triaxial cell, a confining cell pressure and a back-pressure were applied to ensure saturation. The initial effective confining pressure of $30 \mathrm{kPa}$ was subsequently increased in steps so that permeability at different void ratios could be measured.

The permeability tests were performed at low gradients so that a minimal amount of seepage induced consolidation is obtained and the assumption that the coefficient of permeability is constant throughout the sample is justified. Despite such gradients, the flow pump technique allowed a shorter testing time for each permeability measurement. Since this technique is essentially a 'constant heat method' the coefficient of permeability is calculated as

$$
k=\frac{Q L}{A h}
$$

where $Q$ is the constant flow rate imposed by the flow pump, $A$ is the cross-sectional area of the clay sample, $L$ is the height of the sample and $h$ is the excess head of water measured by a differential transducer during a test. The test results obtained for four samples of different heights are shown in Fig. 1 together with the lines given by the Authors' equations (4) and (5). It can be concluded that good agreement between corresponding permeability values is obtainable. The ratio between horizontal and vertical permeabilities for the range of void ratios reported here was approximately equal to 2, as was the case for the results reported in the Paper. A remarkable agreement between absolute values of permeabilities in the two sets of data is noted, though the sample preparation procedure, testing technique and stress paths were significantly different. The results presented here show that the anisotropy of permeability is completely preserved (even after the sample is compressed isotropically) as long as the initial part of the stress path corresponds to one-dimensional com-

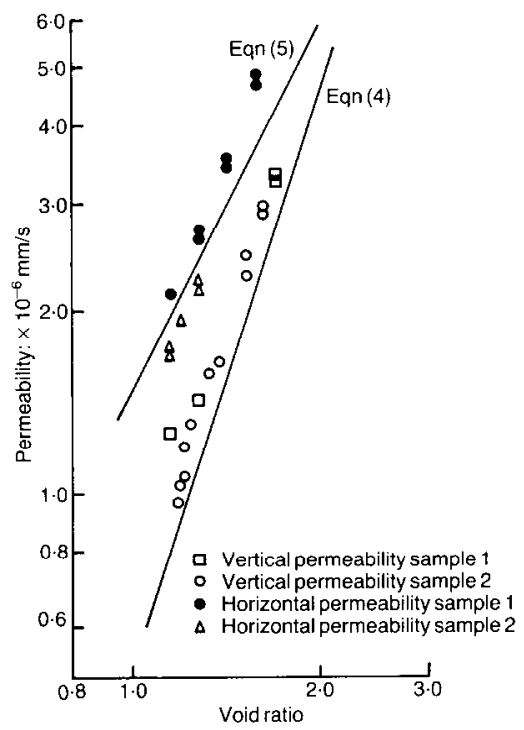

Fig. 1. Relationship between permeability and void ratio 
pression. Thus, our data supports the speculation by the Authors regarding permeability anisotropy for stress paths other than one-dimensional compression.

\section{REFERENCES}

Olsen, H. W., Nichols, R. W. \& Rice, T. L. (1985). Low gradient permeability measurements in a triaxial system. Géotechnique 35, No. 2, 145-157.

Pane, V., Croce, P., Znidarčić, D., Ko, H. Y., Olsen, H. W. \& Schiffman, R. L. (1983). Effects of consolidation on permeability measurements for soft clays. Géotechnique 33, No. 1, 67-72. 